\title{
Integrative Leadership Measure: Construct Development and Content Validity
}

\author{
Sanober Salman Shaikh ${ }^{1}$ \\ ${ }^{1}$ IBA, Unveristy of Sindh, Jamshoro, Pakistan \\ Correspondence: Sanober Salman Shaikh, Institute of Business Adminstration, Univeristy of Sindh, Jamshoro, \\ Pakistan.
}

Received: June 19, 2018

Accepted: August 3, $2018 \quad$ Online Published: August 10, 2018

doi:10.5539/ibr.v11n9p51

URL: https://doi.org/10.5539/ibr.v11n9p51

\begin{abstract}
This article aims to develop framework of integrative leadership, therefore sub objectives were set to achieve the key objective of this study. The sub- objectives of this study were to form definition, initial constructs, and items and examining the content validity of newly developed integrative leadership measure. Thorough understanding and conceptualization of the various leadership styles and their scales was achieved by the review of literature. The integrative leadership definition and its framework were built through integration of six leadership types (transformational, authentic, ethical servant, spiritual and transactional). By means of synthesizing literature on six leadership styles and asseesment of content validity, initial 13 constructs, more than 100 sub- construct and 72 items of integrative leadership were obtained. In future, researchers should focus on examining construct validity and reliability of integrative leadership.
\end{abstract}

Keywords: construct, content validity, integrative leadership, measure

\section{Introduction}

\subsection{Leadership Development and Requirement for Leadership Integration}

The leadership development in the organization is getting progressively more critical and strategically imperative (Leskiw \& Singh, 2007). Leadership development involves developing the leader as a whole, such as the operational, tactical, strategic and personal skills and abilities of manager, how a leader adopts the leadership characteristics and skills and uses them in an efficient manner not only to perform his assigned job duties but also beyond the assigned job duties (Abbas \& Yakoob, 2009). In the current century, there is great need for social and organizational change and holistic leadership (Moxley, 2000). There is a prevalent perception and observation for crises in contemporary leadership. This perception for crunches have motivated researchers and practitioners identical to call for further advanced approaches in leadership (Woolley, Caza \& Levy, 2011). Most of the leadership styles holds isolated components of leadership (Winston \& Patterson, 2006). One can understand that it is not the fault or mistake of scholars, researchers, consultants and leadership practitioners that the leadership has been described in parts or with different styles and has not been described as a whole. Furthermore, Winston and Patterson stated that each researcher's world view is different and none of the existing theories of leadership are wrong. Chemers (2000) stated that research on leadership theories and research on shared thoughts and commonalities among these leadership theories provides a path for integration. Avolio (2007) recognized that research on leadership theories has reached its level of development, and considering the dynamic interaction between leaders and its followers, it requires for advancement and should move to the advance level for integration. Winston and Patterson (2006) proposed the idea of integrative leadership, they highlighted that integrative leadership is comprised of more than 90 variables, which enhances the thorough understanding to leadership researchers and practitioners about scope and breath of integrative leadership. Rost (1993) examined the leadership definitions, and concluded that leadership is based on five-dimensions. Bakker (2002) evaluated the leadership definitions and suggested that leadership is combination of two elements: process and behavior. Fernandez, Cho, and Perry (2010) mentioned that, leadership has been described by different theories, styles, approaches and models. Each leadership theory and leadership style describes the different pieces of the leadership puzzle and many efforts have been taken by researchers for synthesis and integration of leadership such as Njoronge (2015); Soria Snyder \& Reinhard (2015); Ismail, Hussain \& Rashid (2011); Alimo-Metcalfe \& Beasley (2010); Fernandez, Cho \& Perry (2010); Morse (2010); Silvia \& McGuire 
(2010); Real World Group (2010a); Fernandez (2004); VanWart (2003); Yukl (2002). These studies have paid great attention to the theoretical underpinnings and advancement in viable integrative leadership framework and measure. These authors have developed and tested integrated leadership frameworks and models which combines existing knowledge about leadership effectiveness. However, these studies have limited applicability as they have focused on collaborative efforts of stake holders (internal and external) for team and organizational effectiveness and developed specific measures on integrative leadership work in particular context. Moreover, previous studies have not integrated the leadership styles and did not develop integrative leadership definition and its measure as a whole of leadership. Subsequently it appears that there is a lack of suitable valid definition and measure of integrative leadership as a whole. Thus considering the work of (Winston \& Patterson, 2006; Bakker, 2002; Rost, 1993) for leadership effectiveness and leadership success to deal with employee-related issues, the leadership development framework should be established as a whole. Around the globe various studies have confirmed the existence of various types of leadership, which clearly shows that leadership styles such as transactional, transformational, ethical, authentic, spiritual, and servant leadership are widely adopted in work settings and various scales are developed for these leadership styles to measure their constructs. Primarily the current study is designed to develop integrative leadership definition and its measure. There is also strong conceptual and empirical support that leadership styles (such as, transformational, transactional, servant, ethical, authentic, spiritual and paternalistic) share some common behaviors and characteristics (Oner, 2011; Toor \& Ofori, 2009; Brown \& Trevino, 2006; Stone, Russell \& Patterson, 2004). This study develops the definition, constructs and items of integrative leadership measure by integrating leadership behaviors of the six leadership styles (transformational, authentic, ethical, servant, spiritual and transactional), and examines the content validity of integrative leadership constructs.

\subsection{Literature Review}

\subsubsection{Leadership and Its Styles}

Leadership is well-defined and conceptualized with variety of words and ways such as personality, traits, behavior, power, interaction and communication styles, role, and job relationships, and administrative work position (Yukl, 2010). Yukl (2010; 2006) defined leadership as the "process of influencing others to understand and agree about what needs to be done and how to do it, and process of facilitating individual and collective efforts to achieve shared objectives" (p. 8). Leadership is a process through which individual leader inspires, encourages and influences others to accomplish organizational goals. It is also a way through which employees' self-esteem can be encouraged and enhanced for achieving organizational goals (Javaid \& Mirza, 2013, p. 3). The leadership researchers and authors have defined the leadership within different styles and definitions, no single definition of leadership appears to cover every situation. Therefore, this section explains the definitions and concepts of different leadership styles: 1) transformational leadership, 2) authentic leadership, 3) ethical leadership, 4) servant leadership, 5) spiritual leadership and 6) transactional leadership.

\section{1) Transformational Leadership Style}

Bass and Avolio (1990) promoted the ideas of Burns' (1978) and suggested the framework of transformational leadership. Transformational leaders cultivate self-interest and also transcend interest for the "group, organization, or society" (Bass, 1990a, p. 53). Bass (1990) defines transformational leadership as "it occurs when leaders broaden and elevate the interests of their employees, when they create awareness and acceptance of the purposes and mission of the group, and when they stir their employees to look beyond their own self-interest for the good of the group" (p. 21). This kind of leadership is a practice and process to build the commitment of the followers through organization goals and by entrusting the followers with powers to achieve those goals (Yukl, 2010). Transformational leadership is considered leadership of morality and ethics because transformational leadership motivate their group members for team work, serve others, look beyond self- interest for the group purpose (Burns, 1978). Avolio, Waldman and Yammarino (1991) developed four major dimensions that build transformational leadership:

\section{i. Idealized Influence}

Idealized influence is interesting and charismatic aspect of transformational leadership. Under this aspect, the leader becomes a role model and is admired and respected by their followers (Bass, 1998; Bass \& Avolio, 1994). As a result, followers exhibit greater level confidence and trust in their transformational leaders (Jung \& Avolio, 2000; Bass, 1990). The idealized influence element in transformational leadership contains integrity in the form of moral and ethical conduct (Traccy \& Hinkin, 1998; Kanungo \& Mendonca, 1996). The expansion of collective vision is a fundamental dimension of the idealized influence (Jung \& Avolio, 2000). A transformational leader helps their followers to look at the future, and stimulates them to align their personal interest and values with 
purposes of the group and mutual interest (Jung \& Avolio, 2000; Bass, 1998, 1990). Transformational leaders are whole- hearted and enthusiastic to share risk with their followers (Bass, 1998).

\section{ii. Inspirational Motivation}

Inspirational motivation denotes the degree to which leaders provide to their followers a sense of finding goals and purpose in their work and that goal and purpose develops additional goal that is directed strategy for organization (Bass, 1985). It involves communicating vision and generating high performance expectation among the followers. With inspirational motivation, leaders communicate the attractive vision to their followers. These leaders also motivate their followers by assigning work objectives and challenges (Avolio \& Bass, 2002), as cited in Stone, Russell \& Patterson, 2004). Transformational leaders develop spirit of the team, and show enthusiasm and optimism (Bass, 1998, p. 5). To construct relationship, the inspirational leaders build interactive communication with followers, and cultural bond is developed between the leader and member.

\section{iii. Intellectual Stimulation}

Transformational style of leaders inspires followers' "to be innovative and creative by questioning assumptions, reframing problems, and approaching old situations in new way" (Avolio \& Bass, 2002, p. 2); yet the transformational leaders do not publicly criticize their followers but encourage them openly. Transformational leaders ask for creative solution and ideas from their followers for a problem and thereby involve them in problem solving. According to Bass (1990), the intellectually stimulating leaders encourage their followers to try new approaches and emphasize on rationality.

\section{iv. Individualized Consideration}

Avolio and Bass (2002) mentioned that transformational leader pays individual and personal attention to his followers, centered on the individual follower's needs for achievement and growth (as cited in Stone, Russell \& Patterson, 2004). Bass (1998) stated that transformational leader acts as mentor and coach, provides the followers with encouraging and supportive climate to achieve "higher levels of potential" (p. 6). They recognize and accept the different desires and needs of their followers. These leaders build and foster effective listening and two-way communication (Bass, 1998). The leaders delegate task to their followers and unobtrusively monitor those tasks to see if support or guidance is needed to followers. The net effect of individualized consideration and other behavior is empowerment (Behling \& Mcfillen, 1996).

There are a number of versions of scales for measuring transformational leadership, such as the Transformational Leadership Questionnaire (Private sector version) developed by Alban- Metcalfe and Alimo- Metcalfe (2007), and Transformational Leadership Questionnaire (local government version) constructed by Alban- Metcalfe and Alimo- Metcalfe (2000). Multifactor Leadership Questionnaire (MLQ 5X) by Avolio, Bass \& Jung,1999; Bass \& Avolio,1990). Another short measure on Transformational Leadership was given by (Carless, Wearing \& Mann, 2000).

\section{2) Authentic Leadership}

The prevailing literature relating to the authentic leadership notifies that theory of authentic leadership has converged around several underlying dimensions (Walumbwa, Avolio, Gardner, Wernsing \& Peterson, 2008). Luthans and Avolio (2003, p. 243) defined authentic leadership as "a process that draws from both positive psychological capacities and a highly developed organizational context, which results in both greater self-awareness and self-regulated positive behaviors on the part of leaders and associates, fostering positive self-development" (as cited in Walumbwa, Avolio, Gardner, Wernsing \& Peterson, 2008). Luthans and Avolio (2003) and May, Chan, Hodges and Avolio (2003) proposed that authentic leadership comprises positive aspects of morality and high ethical standards that guide behavior and decision making. Authentic leaders are "individuals who are deeply aware of how they think and behave and are perceived by others as being aware of their own and others' moral perspective, knowledge, and strengths; aware of the context in which they operate; and who are confident, hopeful, optimistic, resilient, and high on moral character" (Avolio, Luthans \& Walumbwa, 2004, p. 4). The Gardner, Avolio, Luthans, May and Walumbwa (2005) model of authentic leadership focuses on the core self-awareness and self-regulation components of authentic leadership. They identified several distinguishing features associated with authentic leadership self-regulation processes: internalized regulation, balanced processing of information, relational transparency, and authentic behavior. Walumbwa, Avolio, Gardner, Wernsing and Peterson (2008) developed the authentic leadership model centered on previous definitions and produced multidimensional constructs of authentic leadership, comprising four dimensions, as follows:

Self-Awareness: It is defined to get to know one's own position in the context of other people living around in 
this world and how one can contribute and influence the different phenomena encountered in daily life. It also refers to grasp the real substance of one's own self and explore what one really feels in the context of other's perceptions and its ultimate effects on the society.

Relational Transparency: It is mainly concerned with showing one's true self through providing credible information as to build confidence and showing real emotions and feelings in order to minimize the ambiguity of being fake.

Balanced Processing: This balance processing is practiced by leaders who expose that they accurately evaluate all the relevant data making final decision. Moreover, leaders ask opinions from their followers that challenge their own profoundly held positions.

Internalized Moral Perspective: An internalized and integrated form of self-regulation, which is guided by internal moral standards and values versus group, organizational, and societal pressures, and results in expressed decision-making and behavior that is consistent with these internalized values. The Authentic Leadership Questionnaire (ALQ), 16 items scale was extensively used to measure authentic leadership which is developed by Walumbwa, Avolio, Gardner, Wernsing \& Peterson, 2008)

3) Ethical Leadership

The leadership effectiveness is associated with perceptions of the leader's honesty, integrity, fair, principled and trustworthiness by many researchers (Kuntz, Kuntz, Elenkov \& Nabirukhina, 2013; Eubanks, Brown \& Ybema, 2012; Den Hartog, House, Hanges, Ruiz-Quintanilla, Dorfman \& Globe- Associates, 1999). Trevino, Hartman and Brown (2000) and Trevino, Brown and Hartman (2003) extended conducted exploratory research to understand and examine what is meant by the term ethical leadership. The unstructured interviews were conducted with twenty senior executives and twenty compliance officers in different industries. The interviews' results found that ethical leaders are honest, fair, trustworthy, principled and ethical decision makers and their behaviors in personal and professional life were based on ethics and care about people and society. Moral management is also another important aspect of ethical leadership. The moral management aspect of ethical leadership formulates ethics as explicit dimension of ethical leadership and also portrays the leader's positive and proactive effect on follower's ethical and unethical attitude. The ethical leaders visibly show role modeling ethical behaviors and use reward system (reward and discipline) to grasp followers accountable for their ethical conduct in organization (Trevino, Hartman \& Brown, 2000; Trevino, Brown \& Hartman, 2003). Brown, Trevino and Harrison (2005) merged the two dimensions of ethical leadership under one umbrella and developed definition of ethical leadership as "the demonstration of normatively appropriate conduct through actions and interpersonal relationships, and the promotion of such conduct to followers through two-way communication, reinforcement and decision making" (p. 120). The ethical leaders encourage followers to participate in organizational decision-making and also listen to them. In addition, they perform a role of mentor to their followers and are concerned about the progress, development, and growth needs of followers (Brown \& Trevino, 2006). Moreover, Brown, Trevino and Harrison (2005) established a 10-item scale based on the mentioned literature to measure the several aspects of ethical leadership, popularly known as the Ethical Leadership Scale (ELS). De Hoogh and Den Dartog (2008) proposed another scale for measuring the ethical leadership, consisting of three elements: morality and fairness (fair and honest), role clarification (open communication, clarification of expectations and responsibilities), and power sharing (listening follower's ideas, allowing them to participate in decision making and worrying about them). De Hoogh and Den Dartog used three construct scale to establish ethical leadership measure: morality and fairness- six items; role clarification- five items and power sharing- six items. The De Hoogh and Den Dartog (2008) and Brown, Trevino and Harrison (2005) instrument are considered valid and reliable for measuring ethical leadership.

\section{4) Servant Leadership}

Greenleaf (1970) was the first person who initiated the concept of servant leadership in modern organizational theories. Leadership primarily means to serve others, meet the expectations of others. The servant leadership focuses on others rather than upon self and understands the role of the leader as a servant (Russell \& Stone, 2002; Greenleaf, 1977). Spears (1995a) expanded the servant leadership model to include ten characteristics: listening, empathy, healing, awareness, persuasion, conceptualization, foresight, stewardship, community-building, and growth of people (as cited in Ganoe, 1996). Servant leaders create vision, gain trust and credibility from followers (Farling, Stone \& Winston, 1999). Liden, Wayne, Zhao, and Henderson (2008) developed psychometrically tested multidimensional instrument of servant leadership and suggested seven behaviors (Putting Followers first, Creating Value for the Community, Emotional Healing, Empowering, Helping Followers, Grow and Succeed, Behaving Ethically, conceptual skills). Barbuto and Wheeler (2002) describe 
servant leadership with 11 characteristics: calling, listening, empathy, healing, awareness, persuasion, conceptualization, foresight, stewardship, growth and community building. There are many measurement scale on servant leadership which have received great attention (Greenleaf, 1977; Barbuto \& Wheeler, 2002; Dennis, 2004; Ehrhart, 2004; Sendjaya, 2005; Barbuto \& Wheeler, 2006; Liden et al., 2008).

\section{5) Spiritual Leadership}

The spiritual leadership is formed from an intrinsic model of motivation that integrates the spiritual leadership with three components and their sub components are as follows. Vision is a broad appeal to key stakeholders, destination and journey (Fry, 2003). It reflects high ideals and integrity, does what it takes, encourages hope/faith, and establishes a standard of excellence. Fry (2003) defines vision with three aspects (changing direction, simplifying decisions and coordinating the actions of different people) which serve in creating change. Vision examines the organizational objectives, directs high ambitions, creates sense of meaningful work and develops hope and faith (Daft \& Lengel, 1998). Kotter (1996) proposed that vision refers to image of the future with subsequent description as to why individuals should try hard to develop that future. Altruistic Love is forgiveness, kindness, integrity empathy/compassion, honesty, patience, courage, trust/loyalty, humility. Altruistic love refers to "a sense of wholeness, harmony, and wellbeing produce by care, concern, and appreciation for both and others" (Fry, 2003, p. 712). This definition is built on values and morals such as kindness, honesty, lack of greed, forgiveness, acceptance, patience, appreciation for both self and others, and ability to control and regulate oneself (Reave, 2005; Fry, 2003). Hope and Faith comprising of endurance, perseverance, 'does what it takes' stretches goals, expectations of reward. Hope is a wish with an expectation of accomplishment and faith enhances the possibility that hope will come true and exact. Faith is founded on behaviors, values, and attitudes that show what will happen. Hope and faith create an image for the people where they are going and how to reach there, and create a belief for the people that their vision will be achieved (Fry \& Melanre, 2008; Fry, 2003). Fry and Cohen (2009) stated that "the purpose of spiritual leadership is to tap into the fundamental needs of both leader and follower for spiritual well-being through calling and membership, to create vision and value congruence across the individual, to empower team, and organization levels and, ultimately, to foster higher levels of organizational commitment and productivity (p. 269)". The basic qualities of spiritual leaders are to understand their self and others; good intuition; love; interrelated view of tasks, staff and process and true picture of the future (Altman, 2010). The widely used instrument for measuring spiritual leadership was established by Fry, Vitucci \& Cedillo (2005).

6) Transactional Leadership

Transactional leaders are those who possess task oriented objectives, concentrate on work standards and ensure that they have specific time to attain organizational tasks (Burns, 1978). In addition, they behave in accordance with desires, give extrinsic rewards to their followers, and short term contingent exchanges, negotiate contracts, clarify responsibilities, specify expectations, recognition, and achieve expected performance are the key features of transactional leaders (Bass, 1985). To ensure short-term success, transactional leadership gives followers clarity about rules and standards to protect the status quo and involve closely monitoring and correcting followers' errors (Yukl, 2010; Bass \& Avolio, 1995; Bass, 1985; House, 1971). Transactional leadership is measured by Multifactor Leadership Questionnaire (MLQ form 5X), created by (Bass \& Avolio, 1990; Avolio, Bass \& Jung, 1999).

\subsection{Resemblances among Leadership Styles}

Based on different definitions of leadership, some authors define leadership as a behavior and others deem it to be a process, the term 'leadership' is undoubtedly a multi-dimensional word consisting of certain behaviors, roles and a set of characteristics which in turn is a combination of three or more components (traits, skills, behavior and attitudes). In fact, there are numerous types of leadership behaviors which are ultimately transformed into various leadership styles (Stone, Russell \& Patterson, 2004; Brown \& Trevino, 2006; Toor \& Ofori, 2009; Oner, 2011).

\subsection{Integrative Leadership}

To cognize the concept of integrative leadership, it is necessary to move away from traditional models of dyadic leadership (Alban-Metcalfe \& Alimo-Metcalfe, 2010). Morse (2010, p.233) stated that "majority of leadership theories rest on hierarchical assumption and leader-follower dynamics that break down in the collaborative context." Avolio (2007) recognized that research on leadership theories has reached its level of development and considers the dynamic interaction between leaders and followers. Now, it requires development and moves to the next step which is integration. Fernandez, Cho and Perry (2010) mentioned that development of shared leadership theory encourages scholars to make an effort to integrate. Chemers (2000) stated that functional integration emphasizes on developing and adopting effective leadership characteristics and skills to influence 
followers to achieve the goals. Fernandez, Cho and Perry (2010) indicated in their research that leadership is characterized by different groups of theories, approaches, and models for each group. The leadership literature elaborates that from time-to-time, different theories, models and leadership styles have been developed. These indications show that leadership is not a destination but a journey or a continuous process which needs to be developed over time. Therefore, leadership scholars have emphasized that leadership should be further developed with integrative models and frameworks. Scholars have given different definitions of integrative leadership. For instance, Alban- Metcalfe and Alimo- Metcalfe (2010) defined integrative leadership as shared and collective leadership, in which the person succeeds by collaboratively working with one another. Crosby and Bryson (2010) conceptualized the integrative leadership as "bringing together diverse groups and organization in semi-permanent ways and - typically across sector boundaries - to remedy complex public problems and achieve the common good" (p. 211, as cited in Alban-Metcalfe \& Alimo-Metcalfe, 2010). Fernandez, Cho and Perry (2010) stated that integrated leadership is known as a combination of certain leadership roles, performed by combining the efforts of employees and managers at different levels of hierarchy, such as tasks, relations, change diversity and integrity. The model and framework of integrative leadership includes leadership skills, behaviors, traits, and styles, situational and moderating factors in joint form that explain the leadership effectiveness. (Fernandez, 2004; Yukl, 2002). Integrative leadership is defined as "the antithesis of conception of leadership as a process undertaken by an autonomous, self - determining individuals with a secure unitary identity (who see themselves at) the center of social universe" and a leader "whose behavior is solipsistic and often autocratic" (Alvesson \& Deetz, 2000, p. 89). Integrative leadership is not only bounded by partnership working but it has greater applicability (Huxman \& Vangen, 2005). Some scholars have synthesized leadership knowledge for leadership effectiveness and developed models. They have also tested the integrated leadership models with workplace outcomes (Yukl, 2002; Van Wart, 2003; Fernandez, 2004; Morse, 2010; Silvia \& McGuire, 2010; Fernadez, Cho \& Perry, 2010; Ismail, Hussain \& Rashid, 2011; Njoronge, 2015; Soria, Snyder \& Reinhard, 2015). There are two well know measurement tools to measure integrative leadership. The first is the Board Leadership quality 360-BLQ360; developed by Alimo-Metcalfe and Beasley (2010). In this tool, the integrative leadership is measured in eight dimensions. These eight dimensions are: engaging as effective teams, constructive challenges, ensuring a shared vision, promoting quality and improvement, connecting and influencing effective performance and risk-taking, clarity and accountability, personal qualities and values. The second one is the Partnership Leadership Quality 360 developed by (Real World Group, 2010a). In this tool, the integrative leadership is measured on four scales: commitment to partnership, political skills and system thinking and commissioning.

\section{Research Method}

\subsection{Development of Integrative Leadership Framework for an Integrative Leadership Measure}

This study has two objectives: to develop initial constructs of integrative leadership measure and to examine content validity of integrative leadership constructs. Therefore, the procedure for the development of the integrative leadership measure was performed in two phase: synthesizing the literature and content validity and panel of experts.

\subsubsection{Synthesizing the Literature}

To achieve the first objective, the study develops the initial constructs of an integrative leadership measure, the constructs of integrative leadership were obtained through synthesizing the literature, and three sub-topics are covered under synthesizing the literature: 1) literature review 2) integrative leadership framework and 3) item generation and initial draft of the integrative leadership measure.

\section{1) Literature Review and Construct Analysis}

In this study, the extensive review of existing literature was done to explore the constructs of an integrative leadership measure. A methodological review of the literature was first conducted and then research gaps were identified. The key words used to find and review the literature were: leadership, leadership styles, transformational leadership, ethical leadership, authentic leadership, servant leadership, spiritual leadership and transformational leadership, integrative leadership and their measures. The literature was reviewed by using the published research papers from research journals, journal articles, working papers and $\mathrm{PhD}$ thesis (both published and unpublished).

\section{2) Integrative Leadership Framework}

The integrative leadership framework was built to discover the constructs of the integrative leadership measure. Initially, in this study, similar and dissimilar behaviors, characteristics, skills, traits, and roles of six leadership 
styles (Transformational, Authentic, Ethical, Servant, Spiritual and transactional) were analyzed in the literature review. Then all the interrelated behaviors (characteristics/skills/ traits/roles) were integrated together to develop constructs. These integrated leadership behaviors were selected from six leadership types: Transformational leadership (Yukl, 2010; Avolio \& Bass, 2002; Parry \& Proctor-Thomson, 2002; Jung \& Avolio, 2000; Bass, 1998; Tracey \& Hinkin, 1998; Behling \& McFillen, 1996; Kanungo \& Mendonca, 1996; Bass \& Avolio, 1994; Tracey \& Hinkin, 1994; Avolio, Waldman \& Yammarino, 1991; Bass \& Avolio, 1990; Bass1990a; Bass, 1990b; Burns, 1978; Bass, 1985), Authentic leadership (Walumbwa, Avolio, Gardner, Wernsing \& Peterson, 2008; Gardner, Avolio, Luthans, May \& Walumbwa, 2005; Avolio, Luthans \& Walumbwa, 2004; Luthans \& Avolio, 2003; May et al., 2003). Ethical leadership (Kuntz, Kuntz, Elenkov \& Nabirukhina, 2013; Eubanks, Brown \& Ybema, 2012; De Hoogh \& Den Dartog, 2008; Brown \& Treviño, 2006; Brown, Trevino \& Harrison, 2005; Trevino, Brown \& Hartman, 2003; Trevino, Hartman \& Brown, 2000; Den Hartog et al., 1999; Posner \& Schmidt, 1992), Servant leadership (Liden et al., 2008 Barbuto \& Wheeler, 2006; Barbuto \& Wheeler, 2002; Russell \& Stone, 2002; Greenleaf, 1977), Spiritual leadership (Altman, 2010; Fry \& Cohen, 2009; Fry \& Melanre, 2008; Reave, 2005; Fry, 2003), Transactional leadership (Yukl, 2010; Yukl, 2002; Bass \& Avolio, 1995; Bass, 1985; Burns, 1978; House, 1971). Consequently, for an integrative leadership framework, around 100 behaviors of leaders and 13 constructs were developed by synthesizing the literature. These 13 constructs and their behaviors are as follows.

The integrative leadership constructs developed for this study were: Charismatic leadership (leader acts as a role model, admired and respected by followers); Providing reward and recognition leadership; Commitment to goals and perseverance; Rational leadership (possesses knowledge, the leader has rational rationale and sound reasoning, analyzes data before making decisions); Power sharing/ empowering leadership (shares information, solicits followers' views and opinions, involves followers in problem-solving and decision-making, delegates tasks, encourages followers to followers to use new tactics for old situations, encourages followers to reframe the problems); Visionary/inspirational motivation leadership (has a vision, communicates vision/shows picture of future, shared vision, foresight); Emotional healing leadership (understands the emotions of others, provides a platform for employees to express their emotions); Supportive leadership (acts as coach and mentor, motivates followers with purposeful work/goal, monitoring and correcting followers' errors, provides guidance for achieving goals, persuasion); Ethical leadership (honest and fair, integrity, high ethical standards, avoids unethical behaviour, influences followers in relation to ethical behaviour, ethical and principled decision-making, does not publicly criticize the followers' mistakes, communicates ethics and ethical values); Teamwork-oriented leadership (aligns own work values with others' values, builds teamwork, works for the collective interest, elevates interest of followers, takes and shares followers' risks, builds long-term interpersonal relationship with followers, appeals broadly to key stake holders, looks beyond self-interest); Individualized consideration and altruistic love leadership (aware of others values/aware of others, concern for followers' development and achievement, aware of context/considers individual differences in terms of different needs, concern for society, concern for followers needs/concern about people/cares for others/serves others, humility/forgivingness, acceptance/gratitude/patience/endurance, kindness/ empathy, loyal, involves organizational members in philanthropic activities/builds community spirit); Role clarification/task-oriented leadership (interactive communication/listening/open communication/collaborative communication, builds two-way communication, focuses on work standards, clarifies performance expectation and responsibilities, provides challenges to followers, sets ideal and high goals, negotiates expected performance of followers with rewards/contracts, focuses on short-term goals/takes time to complete task, describes rules and standards, clarifies priorities); Self-awareness /self-regulatory leadership (aware of own values and strength and weaknesses, encourages self to think creatively, confident, optimistic, expresses true feelings, enthusiastic/resilient, hopeful/faithful, practices self-regulation/self-control, appreciates courage by himself).

\section{3) Item Generation and Initial Draft for an Integrative Leadership Measure}

This study developed the uni-dimensional items of IL. Furthermore, the items for measuring the integrative leadership were selected from previous studies. Moreover, the items for measuring the integrative leadership were selected from previous studies (Salanova et al., 2011; Walumbwa, Avolio, Gardner, Wernsing \& Peterson, 2008; Hoogh \& Den Hartog, 2008; Liden et al., 2008; Barbuto \& Wheeler 2006; Brwon, Trevino \& Harrison, 2005; Fry, Vitucci \& Cedillo, 2005; Avolio, Bass \& Jung, 1999; Hartog, Muijen \& Koopman, 1997; Bycio, Hackett \& Allen, 1995). Later, the selected items from review of literature were revised due to the context and sample of the study. In addition, some additional sample items were also developed for certain characteristics/behavior of integrative leadership. 


\subsubsection{Proposed Content Validity by a Panel of Experts}

Consistent with above-mentioned research objectives, the development of the integrative leadership measure was also achieved by checking its content validity. Content validity was conducted for the integrative leadership measure by using the concept of indices of item objective congruence (IOC). The items were incorporated into the IOC form, which was sent to panel of experts (experts in conducting quantitative research, academicians and practitioners). Rovinelli and Hambleton (1977) suggested the idea of index of item-objective congruence. Content validity primarily measures the sufficiency, examines the area of interest and meets the objective (Hinkin, 2005). The indices of the item-objective congruence is a procedure used in test development for evaluating content validity at the item-development stage (Turner and Carlson, 2003). For developing and designing any scale, it is necessary to avoid errors and mistakes in choosing constructs and their measures, it needs to be reviewed by experts (Babbie, 2007). In this study, the IOC form was developed by considering the guidelines of Rovinelli \& Hambleton (1977), in which the items were evaluated by assigning a score of 1 (for clearly measuring power), -1 (clearly not measuring), 0 (degree to which content measurement is not clear or not sure), and a space was provided for writing suggestions. The IOC form and covering letter was sent to all five experts ( 1 advisor, 2 committee members and 2 bank managers), who possessed enough knowledge on the given subjects and were experts in research. These experts were requested to give their feedback and comments on the definitions of the construct and its items in the IOC form. They were requested to evaluate whether each item of the construct measured what is planned to measure, whether items were clearly written and understandable, whether there was any repetition among the items of each construct, and whether there was a need to develop another item to measure any construct. The IOC form and the covering letter were sent to content experts are presented in Appendix A. The basic formula for calculating the IOC was adopted and developed by (Crocker \& Algina, 1986). It is as follows:

$$
I_{i k}=\frac{N}{2 N-2}\left(\mu_{\mathrm{x}}-\mu\right)
$$

Where $I_{i k}$ is the index of item-objective congruence for item $i$ on objective $k, N=$ the number of objectives, $k=$ the judges' mean rating of item $i$ on objective $k$, and $\mu=$ the judges' mean rating of item $i$ on all objectives.

\section{Result}

The five content experts evaluated the validity of the items. After the experts had completed the rating process, the ratings of all the items given by five (5) experts was pooled in a table and the IOC was calculated to obtain the IOC results of measures for each item and for each objective, as suggested by Rovinelli and Hambleton (1977). The item was said to be effective in terms of the IOC if the score of the item was greater than 0.5 (Guntayoung \& Chinchai, 2013). The scores of the items on the IOC are presented in Table 1.

Table 1. Score of Content Validity on the IOC form

\begin{tabular}{|c|c|c|c|c|c|c|c|}
\hline \multirow[b]{2}{*}{ Constructs } & \multirow[b]{2}{*}{ No of Items } & \multicolumn{5}{|c|}{ Scores Rated by (5) Experts } & \multirow{2}{*}{$\begin{array}{l}\text { Content Validity } \\
\text { Score }\end{array}$} \\
\hline & & 1 & 2 & 3 & 4 & 5 & \\
\hline \multirow[t]{2}{*}{ Charismatic Behaviour } & 1 & 1 & 1 & 1 & 1 & 1 & 1.00 \\
\hline & 2 & 1 & -1 & 1 & 1 & 1 & 0.6 \\
\hline $\begin{array}{lll}\text { Providing } & \text { Rewards } & \text { and }\end{array}$ & 1 & 1 & 1 & 0 & 1 & 1 & 0.8 \\
\hline Recognition of Behaviour & 2 & 1 & 1 & 0 & 1 & 1 & 0.8 \\
\hline \multirow[t]{3}{*}{ Rational Behaviour } & 1 & 1 & 1 & 1 & 1 & 1 & 1.00 \\
\hline & 2 & 1 & 0 & 1 & 1 & -1 & 0.4 \\
\hline & 3 & 1 & 1 & 1 & 1 & 1 & 1.00 \\
\hline \multirow{2}{*}{$\begin{array}{lcc}\text { Commitment with goals } \\
\text { /Perseverance Behaviour }\end{array}$} & 1 & 1 & 1 & 1 & 1 & 1 & 1.00 \\
\hline & 2 & 1 & 1 & 1 & 1 & 1 & 1.00 \\
\hline \multirow{2}{*}{$\begin{array}{l}\text { Visionary/Inspirational } \\
\text { motivation }\end{array}$} & 1 & 1 & 1 & 0 & 1 & 1 & 0.8 \\
\hline & 2 & 1 & 1 & 0 & 1 & 1 & 0.8 \\
\hline \multirow[t]{2}{*}{ Behaviour } & 3 & 1 & 1 & 1 & 1 & 1 & 1.00 \\
\hline & 4 & 1 & 1 & 1 & 1 & -1 & 0.6 \\
\hline \multirow[t]{2}{*}{ Emotional Healing Behaviour } & 1 & 1 & 0 & 1 & 1 & 1 & 0.8 \\
\hline & 2 & 1 & 1 & 0 & 1 & 1 & 0.8 \\
\hline \multirow[t]{5}{*}{ Supportive Behaviour } & 1 & 1 & 1 & 1 & 1 & 1 & 1.00 \\
\hline & 2 & 1 & 1 & 1 & 1 & 1 & 1.00 \\
\hline & 3 & 1 & 1 & 1 & 1 & 1 & 1.00 \\
\hline & 4 & 1 & 1 & 1 & 1 & 1 & 1.00 \\
\hline & 5 & 1 & 1 & 1 & 1 & 1 & 1.00 \\
\hline
\end{tabular}




\begin{tabular}{|c|c|c|c|c|c|c|c|}
\hline \multirow[b]{2}{*}{ Constructs } & \multirow[b]{2}{*}{ No of Items } & \multicolumn{5}{|c|}{ Scores Rated by (5) Experts } & \multirow{2}{*}{$\begin{array}{l}\text { Content Validity } \\
\text { Score }\end{array}$} \\
\hline & & 1 & 2 & 3 & 4 & 5 & \\
\hline \multirow[t]{9}{*}{ Ethical Behaviour } & 1 & 1 & 1 & 1 & 1 & 1 & 1.00 \\
\hline & 2 & 1 & 1 & 1 & 1 & 1 & 1.00 \\
\hline & 3 & 1 & 1 & 1 & 1 & 1 & 1.00 \\
\hline & 4 & 1 & 0 & 1 & 1 & 0 & 0.6 \\
\hline & 5 & 1 & 0 & 1 & 1 & 1 & 0.8 \\
\hline & 6 & 1 & 1 & 1 & 1 & 1 & 1.00 \\
\hline & 7 & 1 & 1 & 1 & 1 & 1 & 1.00 \\
\hline & 8 & 1 & 1 & 1 & 1 & 1 & 1.00 \\
\hline & 9 & 1 & 1 & 1 & 1 & 1 & 1.00 \\
\hline Power sharing & 1 & 1 & 1 & 1 & 1 & 1 & 1.00 \\
\hline \multirow[t]{4}{*}{ /Empowering Behaviour } & 2 & 1 & 1 & 1 & 1 & 1 & 1.00 \\
\hline & 3 & 1 & 1 & 1 & 1 & 1 & 1.00 \\
\hline & 4 & 1 & 1 & 1 & 1 & 1 & 1.00 \\
\hline & 5 & 1 & 1 & 1 & 1 & 1 & 1.00 \\
\hline \multirow[t]{8}{*}{ Teamwork-Oriented Behaviour } & 1 & 1 & 0 & 0 & -1 & 0 & 0 \\
\hline & 2 & 1 & 1 & 1 & 1 & 1 & 1.00 \\
\hline & 3 & 1 & 1 & 1 & 1 & 1 & 1.00 \\
\hline & 4 & 1 & -1 & 1 & 1 & 1 & 0.2 \\
\hline & 5 & 1 & -1 & 1 & 1 & 1 & 0.8 \\
\hline & 6 & 1 & 0 & 1 & 1 & 1 & 0.8 \\
\hline & 7 & 1 & 0 & 1 & 1 & 1 & 0.8 \\
\hline & 8 & 1 & 0 & 1 & 1 & 1 & 0.8 \\
\hline \multirow{10}{*}{$\begin{array}{l}\text { Individualized Consideration } \\
\text { and Altruistic love /Behaviour }\end{array}$} & 1 & 1 & 1 & 1 & 1 & 1 & 1.00 \\
\hline & 2 & 1 & -1 & 1 & 1 & 1 & 0.6 \\
\hline & 3 & 1 & 1 & 1 & 1 & 1 & 1.00 \\
\hline & 4 & 1 & 0 & 1 & 1 & 1 & 0.8 \\
\hline & 5 & 1 & 0 & 1 & 1 & 1 & 0.8 \\
\hline & 6 & 1 & 1 & 0 & 1 & 1 & 0.8 \\
\hline & 7 & 1 & -1 & 1 & 1 & 1 & 0.6 \\
\hline & 8 & 1 & 1 & 1 & 1 & 1 & 1.00 \\
\hline & 9 & 1 & 1 & 0 & 1 & 1 & 0.8 \\
\hline & 10 & 1 & 1 & 1 & 1 & 1 & 1.00 \\
\hline Role Clarification/ & 1 & 1 & 1 & 0 & 1 & 1 & 0.8 \\
\hline \multirow[t]{8}{*}{ Task-oriented Behaviour } & 2 & 1 & -1 & 1 & 1 & 1 & 0.6 \\
\hline & 3 & 1 & 1 & 1 & 1 & 1 & 1.00 \\
\hline & 4 & 1 & 1 & 1 & 1 & 1 & 1.00 \\
\hline & 5 & 1 & 1 & 1 & 1 & 1 & 1.00 \\
\hline & 6 & 1 & 0 & 1 & 1 & 1 & 0.8 \\
\hline & 7 & 1 & 0 & 1 & 1 & 0 & 0.6 \\
\hline & 8 & 1 & 1 & 1 & 1 & 1 & 1.00 \\
\hline & 9 & 1 & 1 & 1 & 1 & 1 & 1.00 \\
\hline Self-awareness/Self-Regulatory & 1 & 1 & 1 & 1 & 1 & 1 & 1.00 \\
\hline \multirow[t]{10}{*}{ Behaviour } & 2 & 1 & 1 & 1 & 1 & 1 & 1.00 \\
\hline & 3 & 1 & 1 & -1 & 1 & 1 & 0.6 \\
\hline & 4 & 1 & 0 & 1 & 1 & 1 & 0.8 \\
\hline & 5 & 1 & 1 & 1 & 1 & 1 & 1.00 \\
\hline & 6 & 1 & 1 & 1 & 1 & 1 & 1.00 \\
\hline & 7 & 1 & 1 & 1 & 1 & 1 & 1.00 \\
\hline & 8 & 1 & 0 & 1 & 1 & -1 & 0.4 \\
\hline & 9 & 1 & 0 & 1 & 1 & -1 & 0.4 \\
\hline & 10 & 1 & 1 & 1 & 1 & 1 & 1.00 \\
\hline & 11 & 1 & 1 & 1 & 1 & 1 & 1.00 \\
\hline
\end{tabular}

Once the integrative leadership measure was developed, it was revised by the advisor. The proposed items of integrative leadership measure achieved the scores on IOC by five experts, it was found that five items of the IL measure had a low IOC scores and they needed to be rewritten as suggested by the IOC experts in this study, and those of low reliability items were revised. None of items were removed from the integrative leadership measure after the IOC score because there was only one item for each behavior in the constructs.

\subsection{Item Scaling of the Integrative Leadership}

Once the content validity of the constructs was obtained and the items were refined, the next step was to set the scale of items. For the integrative leadership six points Likert scale: strongly agree, agree, somewhat agree, 
somewhat disagree, disagree, and strongly disagree were used to collect the data from the study's participants Likert- type scale were broadly used scale in one's survey research (Cook, Trapp \& Williams, 1981), and the coefficient alpha reliability increased with Likert scales up to the use of the 5 to 7 Likert scale (Hinkin, 2005).

\section{Discussion}

This research article was written to develop definition, initial constructs, and items and to measure content validity of the integrative leadership measure. The extensive review of the literature was done and the operational definition of integrative leadership was derived from six types of leadership (transformational, authentic, ethical, servant, spiritual and transactional). The behaviors under these six leadership styles were integrated and constructs and their items were developed. The developed items were obtained from existing scales available on various leadership styles, and were revised and some new item were also built. Kuhn (1996) stated that new approaches and frameworks should be developed when existing paradigms and models are insufficient in explaining the perceived phenomena. Past leadership research involved research theory in periodic form; such as one theory focusing on trait leadership at one time; cognitive, situational leadership, charismatic leadership at another time (Chemers, 2000). These leadership theories systematically define shared findings and streams of thought across theoretical perspectives. In the last, the content validity of developed items was evaluated. Overall, it was concluded that integrative leadership is a multidimensional process in which leaders possess traits, characteristics, skills, and perform various roles and behaviors, comprising of 13 constructs such as: Charismatic Leadership, Providing Reward and Recognition Leadership, Commitment with Goals and Perseverance Leadership, Rational Leadership, Power Sharing/Empowering Leadership, Visionary/Inspirational Motivation Leadership, Emotional Healing Leader, Supportive Leadership, Ethical Leadership, Team- Oriented Leadership, Individualized Consideration and Altruistic Love Leadership, Role Clarification/Task-Oriented Leadership and Self -Awareness/ Self- Regulation Leadership. The definition of integrative leadership was consistent with previous definitions of integrative leadership given by Winston \& Patterson (2006), Fernandez, Cho and Perry, (2010), Bakker (2002) Chemers (2000) and Rost (1993). This study found that most of the integrative leadership constructs name cannot be seen as the same as particular constructs in any existing leadership style and in integrative leadership. The leadership researchers provide new theories, findings and results, which originate to understand leadership differently, but integrative leadership provides an avenue to cognize whole of leadership (Winston \& Patterson, 2006). The name of each construct of integrative leadership seems innovative and rare due to the integration of various leadership styles. Many dimensions of the integrative leadership are virtuous (Winston \& Patterson, 2006). The definition and measure of IL was supported by Weber (1947). Weber (1947) claimed that the nature and type of leadership depends on the culture of that organization. This study followed the principle of facet theory (Donald, 1995) for developing IL measures; and that statement of each item was redrafted and revised because behavior is always influenced by culture (Hofsted, 2001). Chemers (2000) stated that functional integration helps in making an effort and emphasizes on developing and adopting effective leadership characteristics and skills to influence followers in order to achieve the goals. Hence, it can be said that integrative leadership is novel approach, different from old theories of leadership. It may be amalgamation or combination of leadership styles consisting different characteristics, trait, skills, behaviors, and roles. It creates a notion of shared leadership (between employees and managers) for leadership effectiveness and influences followers to achieve organizational goals

\section{Implications and Recommendations for Future Research}

The current study provides advantages to human resource and leadership scholars, HR professionals and managers of various organizations. The current study is addition to academic literature as it contributes literature with revised and theorized definition of integrative leadership, and developed initial constructs of integrative leadership measure. The future researcher may adopt definitions, constructs and developed items of integrative leadership for the purpose of further development and upgradation. Another key finding of this study is that it provides implications and recommendations in the area of leadership development. Leaders may use this integrative leadership framework in their leadership development plan. Organization may also use the integrative leadership characteristics when recruiting managers or leaders. In addition, the integrative leadership framework may help the top management, supervisors and middle level managers, greatly, in the development of leadership plans and leadership reports. Integrative leadership creates a notion of shared leadership (between employees and managers) for leadership effectiveness and influences followers to achieve organizational goals.

To enhance authenticity of the integrative leadership measure, future researcher should study the psychometric properties of integrative measure. Therefore, it is recommended that data should be collected form large number of respondents who are working in different industries. Moreover, research should adopt confirmatory factor analysis to evaluate construct validity, criterion validity and reliability analysis of 13 constructs of integrative 
measurement tool. The integrative leadership can be further refined and developed in to the existing leadership models. Therefore, future researchers are directed to incorporate the advanced leadership types such as benevolent leadership, paternalistic leadership into proposed integrative leadership framework in order to expand the scope of integrative leadership model.

\section{References}

Abbas, Q., \& Yaqoob, S. (2009). Effect of leadership development on employee performance in Pakistan. Pakistan Economic and Social Review, 47(2), 269-292.

Alban-Metcalfe, J., \& Alimo-Metcalfe, B. (2000). An analysis of the convergent and discriminant validity of the transformational leadership questionnaire. International Journal of Selection and Assessment, 8(3), 158-175. https://doi.org/10.1111/1468-2389.00144

Alban-Metcalfe, J., \& Alimo-Metcalfe, B. (2007). Development of a private sector version of the (engaging) transformational leadership questionnaire. Leadership \& Organization Development Journal, 28(2), 104-121. https://doi.org/10.1108/01437730710726813

Alban-Metcalfe, J., \& Alimo-Metcalfe, B. (2010). Integrative leadership, partnership working and wicked problems: A conceptual analysis. International Journal of Leadership in Public Services, 6(3), 3-13. https://doi.org/10.5042/ijlps.2010.0512

Alimo-Metcalfe, B \& Beasley, K. (2010). Construction of the board leadership quality 360-BLQ360 (Working Paper). Leeds, Real World Group.

Altman, Y. (2010). In search of spiritual leadership: Making a connection with transcendence. Human Resource Management International Digest, 18(6), 35-38. https://doi.org/10.1108/09670731011071764

Alvesson, M., \& Deetz, S. (2000). Doing Critical Management Research. London: Sage. https://doi.org/10.4135/9781849208918

Avolio, B. J. (2007). Promoting more integrative strategies for leadership theory-building. American Psychologist, 62(1), 25. https://doi.org/10.1037/0003-066X.62.1.25

Avolio, B. J., \& Bass, B. M. (2002). Developing potential across a full range of leadership cases on transactional and transformational leadership. Mahwah, NJ: Lawrence Erlbaum Associates.

Avolio, B. J., Bass, B. M., \& Jung, D. I. (1999). Re- examining the components of transformational and transactional leadership using multifactor leadership questionnaire. Journal of Occupational and Organizational Psychology, 72 (4), 441-462. https://doi.org/10.1348/096317999166789

Avolio, B., Luthans, F., \& Walumbwa, F. O. (2004). Authentic leadership: Theory-building for veritable sustained performance (Working paper). Gallup Leadership Institute, University of Nebraska, Lincoln.

Avolio, B., Waldman, D., \& Yammarino, F. (1991). Leading in the 1990s: The four is of transformational leadership. Journal of European Industrial Training, 15(4), 9-16. https://doi.org/10.1108/03090599110143366

Babbie, E. R. (12th Eds.). (2010). Introduction to social research. Belmont, CA: Wadsworth Cengage Learning.

Barbuto Jr, J. E., \& Wheeler, D. W. (2006). Scale development and construct clarification of servant leadership. Group \& Organization Management, 31(3), 300-326. https://doi.org/10.1177/1059601106287091

Barbuto, J. E.м \& Wheeler, D. W. (2002). Becoming a servant leader: Do you have what it takes? University of Nebraska, Lincoln.

Barker, R. A. (2002). On the nature of leadership. Lanham: University Press of America.

Bass, B. M. (1985). Leadership and performance beyond expectation. New York: The Free Press.

Bass, B. M. (1990). Bass and Stogdill's Handbook of Leadership: Theory, Research and Management Applications (3rd ed.). s. New York: The Free Press.

Bass, B. M. (1990a). Bass and stogdill's Handbook of leadership: Theory, Research, and Managerial Applications (3rd ed.). New York: The Free Press.

Bass, B. M. (1990b). From transactional to transformational leadership: Learning to share the vision. Organizational Dynamics, 18(3), 19-31. https://doi.org/10.1016/0090-2616(90)90061-S

Bass, B. M. (1998). Transformational leadership: Industrial, military, and educational impact. Mahwah, NJ: Lawrence Erlbaum Associates. 
Bass, B. M., \& Avolio, B. J. (1990). Multifactor leadership questionnaire. Palo Alto, CA: Consulting Psychologist Press.

Bass, B. M., \& Avolio, B. J. (1995). MLQ multifactor leadership questionnaire. Redwood City, CA: Mind Garden.

Bass, B.M. \& Avolio, B.J. (Ed.). (1994). Improving organizational effectiveness through transformational leadership. Thousand Oaks, CA: Sage.

Behling, O. \& McFillen, J. M. (1996). A syncretical model of charismatic/transformational leadership. Group and Organizational Management, 21(2), 163-191. https://doi.org/10.1177/1059601196212004

Brown, M. E., \& Trevino, L. K. (2006). Ethical leadership: A review and future directions. The Leadership Quarterly, 17(6), 595-616. https://doi.org/10.1016/j.leaqua.2006.10.004

Brown, M. E., Trevino, L. K., \& Harrison, D. A. (2005). Ethical leadership: A social learning perspective for construct development and testing. Organizational Behavior and Human Decision Processes, 97(2), 117-134. https://doi.org/10.1016/j.obhdp.2005.03.002

Burns, J. M. (1978). Leadership. New York: Harper Torch books.

Bycio, P., Hackett, R. D., \& Allen, J. S. (1995). Further assessments of Bass's (1985) conceptualization of transactional and transformational leadership. Journal of Applied Psychology, 80(4), 468. https://doi.org/10.1037/0021-9010.80.4.468

Carless, S. A., Wearing, A. J., \& Mann, L. (2000). A short measure of transformational leadership. Journal of Business and Psychology, 14(3), 389-405. https://doi.org/10.1023/A:1022991115523

Chemers, M. M. (2000). Leadership research and theory: A functional integration. Group Dynamics. Theory, Research, and Practice, 4(1), 27. https://doi.org/10.1037/1089-2699.4.1.27

Cook, R. W., Trapp, A. L., \& Williams, J. F. (1981). Pathology of Taenia taeniaformis infection in the rat: Hepatic, lymph node and thymic changes. Journal of Comparative Pathology, 91(2), 219-226. https://doi.org/10.1016/0021-9975(81)90026-8

Crocker, L., \& Algina, J. (1986). Introduction to classical and modern test theory. Toronto: Holt, RineHart, and Winston, Inc.

https://nsuworks.nova.edu/cgi/viewcontent.cgi?referer=https://scholar.google.com.pk/\&httpsredir=1\&article $=1870 \&$ context $=\mathrm{tqr} /$

Crosby, B. C., \& Bryson, J. M. (2010). Integrative leadership and the creation and maintenance of cross-sector collaborations. The Leadership Quarterly, 21(2), 211-230. https://doi.org/10.1016/j.leaqua.2010.01.003

Daft, R. L., \& Lengel, R. H. (1998). Fusion leadership: Unlocking the subtle forces that change people and organization. San Francisco, CA: Berrett- Koehler Publishers.

De Hoogh, A. H. B., \& Den Dartog, D. N. (2008). 'Ethical and despotic leadership, relationships with leader's social responsibility, top management team effectiveness and subordinates' optimism: A multi- method study'. The Leadership Quarterly, 19(3), 297-311. https://doi.org/10.1016/j.leaqua.2008.03.002

Den Hartog, D. N., House, R. J., Hanges, P. J., Ruiz-Quitanilla, S. A., Dorfman, P. W., \& Globe-Associates. (1999). Culture specific and cross culturally generalizable implicit leadership theories: Are attributes of charismatic/transformational leadership universally endorsed? The Leadership Quarterly, 10(2), 219-256. https://doi.org/10.1016/S1048-9843(99)00018-1

Dennis, S. R. (2004). Servant leadership theory: Development of the servant leadership assessment instrument (Unpublished doctoral dissertation). School of Leadership Studies, Regent University, Virginia Beach, VA.

Donald, L. (1995). Facet theory: Defining research domain. In G. M. Breakwell., S. Hammond., \& C. Fife-Schaw (Eds.), Research Methods in Psychology (116-37). SAGE, London.

Ehrhart, M. G. (2004). Leadership and procedural justice climate as antecedents of unit level organizational citizenship behavior. Personnel Psychology, 57(1), 61-94. https://doi.org/10.1111/j.1744-6570.2004.tb02484.x

Eubanks, D. L., Brown, A. D., \& Ybema, S. (2012). Leadership, identity, and ethics. Journal of Business Ethics, 107(1), 1-3. https://doi.org/10.1007/s10551-012-1295-5

Farling, M. L., Stone, A. G., \& Winston, B. E. (1999). Servant leadership: Setting the stage for empirical research. Journal of Leadership \& Organizational Studies, 6(1-2), 49-72. 
https://doi.org/10.1177/107179199900600104

Fernandez, S. (2004). Developing and testing an integrative framework of public sector leadership: Evidence from the public education arena. Journal of Public Administration Research and Theory, 15(2), 197-217. https://doi.org/10.1093/jopart/mui014

Fernandez, S., Cho, Y. J., \& Perry, J. L. (2010). Exploring the link between integrated leadership and public sector performance. The Leadership Quarterly, 21(2), 308-323. https://doi.org/10.1016/j.leaqua.2010.01.009

Fry, L. W. (2003). Toward a theory of spiritual leadership. The Leadership Quarterly, 14(6), 693-727. https://doi.org/10.1016/j.leaqua.2003.09.001

Fry, L. W., \& Cohen, M. P. (2009). Spiritual leadership as a paradigm for organizational transformation and recovery from extended work hours' cultures. Journal of Business Ethics, 84(1), 265-278. https://doi.org/10.1007/s10551-008-9695-2

Fry, L. W., Vitucci, S., \& Cedillo, M. (2005). Transforming the army through spiritual leadership. The Leadership Quarterly, 16(5), 835-862. https://doi.org/10.1016/j.leaqua.2005.07.012

Ganoe, F. J. (1996). Reflections on Leadership: How Robert K. Greenleaf's Theory of Servant-Leadership Influenced Today's Top Management Thinkers. Journal of Systems Management, 47(3), 62.

Gardner, W. L., Avolio, B. J., Luthans, F., May, D. R., \& Walumbwa, F. O. (2005). “Can you see the real me?” A self-based model of authentic leader and follower development. The Leadership Quarterly, 16, 343-372. https://doi.org/10.1016/j.leaqua.2005.03.003

Greenleaf, R. K. (1970). The servant as leader. Indianapolis: The Robert K. Greenleaf Center.

Greenleaf, R. K. (1977). Servant leadership: A journey into the nature of legitimate power and greatness. New York, NY: Paulist Press.

Guntayoung, C., \& Chinchai, S. (2013). The content validity and test-retest reliability of the developmental visual perception test (DTVP-2) in Thai children. International Journal of Medicine and Pharmaceutical Sciences, 1(3), 1-6.

Hartog, D. N., Muijen, J. J., \& Koopman, P. L. (1997). Transactional versus transformational leadership: An analysis of the MLQ. Journal of Occupational and Organizational Psychology, 70(1), 19-34. https://doi.org/10.1111/j.2044-8325.1997.tb00628.x

Hinkin, T. R. (2005). Scale development principles and practices. In R. A. Swanson, \& E.F. Holton III (Eds.), Research in organizations: foundations and methods of inquiry (pp. 161- 179). San Francisco: Berrett-Koehler Publishers Inc.

Hofstede, G. (2001). Culture's consequences: Comparing values, behaviors, institutions, and organizations across nations (2nd ed.). Thousand Oaks, CA: Sage.

House, R. J. (1971). A path goal theory of leader effectiveness. Administrative Science Quarterly, 16(3), 321-339. https://doi.org/10.2307/2391905

http://kentblumberg.typepad.com/kent_blumberg/files/servant_leadership_by_univ_of_nebraska.pdf

Huxham, C., \& Vangen, S. (2005). Managing to collaborate: The theory and practice of collaborative advantage. New York: Routledge.

Ismail, W. K. W., Hussain, G., \& Rashid, M. A. (2011). Integrative framework of leadership effectiveness. International Journal of Business and Social Science, 2(2), 126-132.

Javaid, M. F., \& Mirza, M. U. (2013). Leadership style enhances the employee organizational commitment: A case study of educational institutions in Lahore. Paper presented in International Journals and Conference of management, Retrieved from URL: http://localhost/icjmsss.

Jung, D. I., \& Avolio, B. J. (2000). Opening the black box: An experimental investigation of the mediating effects of trust and value congruence on transformational and transactional leadership. Journal of Organizational Behavior, 21(8), 949-964. https://doi.org/10.1002/1099-1379(200012)21:8<949::AID-JOB64>3.0.CO;2-F

Kanungo, R. N., \& Mendonca, M. (1996). Ethical dimensions of leadership. Thousand Oaks, CA: Sage.

Kotter, J. P. (1996). Leading change. Boston. Harvard Business School Press. 
Kuhn, T. (1996). The structure of scientific revolutions(3rd ed.). Chicago: The University of Chicago Press. https://doi.org/10.7208/chicago/9780226458106.001.0001

Kuntz, J. R. C., Kuntz, J. R., Elenkov, D., \& Nabirukhina, A. (2013). Characterizing ethical cases: A cross-cultural investigation of individual differences, organizational climate, and leadership on ethical decision-making. Journal of Business Ethics, 113(2), 317-331. https://doi.org/10.1007/s10551-012-1306-6

Leskiw, S. L., \& Singh, P. (2007). Leadership development: Learning from best practices. Leadership \& Organization Development Journal, 28(5), 444-464. https://doi.org/10.1108/01437730710761742

Liden, R. C., Wayne, S. J., Zhao, H., \& Henderson, D. (2008). Servant leadership: Development of a multidimensional measure and multi-level assessment. The Leadership Quarterly, 19(2), 161-177. https://doi.org/10.1016/j.leaqua.2008.01.006

Luthans, F., \& Avolio, B. J. (2003). Authentic leadership development. In K. S. Cameron, J. E. Dutton, \& R. E. Quinn (Eds.). Positive organizational scholarship, pp. 241-258. San Francisco: Berrett-Koehler.

May, D. R., Chan, A., Hodges, T., \& Avolio, B. J. (2003). Developing the moral component of authentic leadership. Organizational Dynamics, 32(3), 247-260. https://doi.org/10.1016/S0090-2616(03)00032-9

Morse, R. S. (2010). Integrative public leadership: Catalyzing collaboration to create public value. The Leadership Quarterly, 21(2), 231-245. https://doi.org/10.1016/j.leaqua.2010.01.004

Moxley, R. S. (2000). Leadership and spirit. Jossey-Bass, San Francisco: CA.

Njoroge, D. (2015). The effect of integrative leadership style on organizational commitment as moderated by employee participation in technical institutions in Kenya. Strategic Journal of Business \& Change Management, 2(4), 52-71.

Oner, Z. H. (2012). Servant leadership and paternalistic leadership styles in the Turkish business context: A comparative empirical study. Leadership \& Organization Development Journal, 33(3), 300-316. https://doi.org/10.1108/01437731211216489

Parry, K. W., \& Proctor-Thomson, S. B. (2002). Perceived integrity of transformational leaders in organizational settings. Journal of Business Ethics, 35(2), 75-96. https://doi.org/10.1023/A:1013077109223

Posner, B. Z., \& Schmidt, W. H. (1992). Values and the American manager. An update updated. California Management Review, 34, 80-94. https://doi.org/10.2307/41167425

Real World Group. (2010a). Partnership working 360. Leeds: Real World Group. Retrievd from https://realworld-group.com/files/integrative-leadership-systems-thinking-and-wicked-problems-570f82a76 f9da.pdf

Reave, L. (2005). Spiritual values and practices related to leadership effectiveness. The Leadership Quarterly, 16(5), 655-687. https://doi.org/10.1016/j.leaqua.2005.07.003

Rost, J. C. (Ed.). (1993). Leadership for the twenty-first century. Westport, CT: Praeger.

Rovinelli, R. J., \& Hambleton, R. K. (1977). On the use of content specialists in the assessment of criterionreferenced test item validity. Dutch Journal of Educational Research, 2, 4-60.

Russell, R. F., \& Stone, A. G. (2002). A review of servant leadership attributes: Developing a practical model. Leadership and Organization Development Journal, 23(3), 145-157. https://doi.org/10.1108/01437730210424

Salanova, M., Lorente, L., Chambel, M. J., \& Martínez, I. M. (2011). Linking transformational leadership to nurses' extra - role performance: the mediating role of self - efficacy and work engagement. Journal of Advanced Nursing, 67(10), 2256-2266. https://doi.org/10.1111/j.1365-2648.2011.05652.x

Sendjaya, S. (2005). Development and validation of the servant leadership behavior scale (Unpublished term paper). School of Leadership Studies, Regent University

Silvia, C., \& McGuire, M. (2010). Leading public sector networks: An empirical examination of integrative leadership behaviors. The Leadership Quarterly, 21(2), 264-277. https://doi.org/10.1016/j.leaqua.2010.01.006

Soria, K., Snyder, S., \& Reinhard, A. P. (2015). Strengthening college students' integrative leadership orientation by building a foundation for civic engagement and multicultural competence. Journal of leadership Education. https://doi.org/10.12806/V14/I1/R4 
Spears, L. C. (Ed.). (1995a). Reflections on leadership: How Robert K. Greenleaf's theory of servant-leadership influenced today's top management thinkers. Atlanta, GA: Greenleaf Center.

Stone, A. G., Russell, R. F., \& Patterson, K. (2004). Transformational versus servant leadership: A difference in leader focus. Leadership \& Organization Development Journal, 25(4), 349-361. https://doi.org/10.1108/01437730410538671

Toor, S. R., \& Ofori, G. (2009). Ethical leadership: Examining the relationships with full range leadership model, employee outcomes, and organizational culture. Journal of Business Ethics, 90(4), 533-547. https://doi.org/10.1007/s10551-009-0059-3

Tracey, J. B. \& Hinkin, T. R. (1998). Transformational leadership or effective managerial practices? Group \& Organization Management, 23(3), 220-236. https://doi.org/10.1177/1059601198233002

Tracey, J. B., \& Hinkin, T. R. (1994). Transformational leaders in the hospitality industry. Cornell Hotel and Restaurant and Administration Quarterly, 35(2), 18-24. https://doi.org/10.1177/001088049403500213

Trevino, L. K., Brown M., \& Hartman, L. P. (2003). A qualitative investigation of perceived executive ethical leadership: Perceptions from inside and outside the executive suite. Human Relations, 55(1), 5-37. https://doi.org/10.1177/0018726703056001448

Trevino, L. K., Hartman, L. P., \& Brown, M. (2000). Moral person and moral manager: How executives develop a reputation for ethical leadership. California Management Review, 42(4), 128-142. https://doi.org/10.2307/41166057

Turner, R. C., \& Carlson, L. (2003). Indexes of item-objective congruence for multidimensional items. International Journal of Testing, 3(2), 163-171. https://doi.org/10.1207/S15327574IJT0302_5

Van Wart, M. (2003). Public-sector leadership theory: An assessment. Public Administration Review, 23, 214-228. https://doi.org/10.1111/1540-6210.00281

Walumbwa, F. O., Avolio, B. J., Gardner, W. L., Wernsing, T. S., \& Peterson, S. J. (2008). Authentic leadership: Development and validation of a theory-based measure. Journal of Management, 34(1), 89-126. https://doi.org/10.1177/0149206307308913

Weber, M. (1947). The theory of social and economic organization. New York: Free Press.

Winston, B. E., \& Patterson, K. (2006). An integrative definition of leadership. International Journal of Leadership Studies, 1(2), 6-66.

Woolley, L., Caza, A., \& Levy, L. (201). Authentic leadership and follower development: Psychological capital positive work climate and gender. Journal of Leadership and Organizational Studies, 18(4), 438-448. https://doi.org/10.1177/1548051810382013

Yukl, G. (5th Ed.). (2002). Leadership in organizations. Upper Saddle River, NJ: Prentice Hall.

Yukl, G. (6th Ed.). (2006). Leadership in organizations. Englewood Cliffs, NJ: Prentice Hall.

Yukl, G. (7th Ed.). (2010). Leadership in organizations. Upper Saddle River, NJ: Prentice Hall.

\section{Copyrights}

Copyright for this article is retained by the author(s), with first publication rights granted to the journal.

This is an open-access article distributed under the terms and conditions of the Creative Commons Attribution license (http://creativecommons.org/licenses/by/4.0/). 